\title{
DESIGNING ENGLISH SYLLABUS FOR DINIYAH PROGRAM BASED ON STUDENT'' NEED ANALYSIS AT BABUSSALAM SELAYAR
}

\author{
St. Naftari \\ Universitas Islam Negeri Alauddin Makassar \\ naftarisity@gmail.com \\ St. Azisah \\ Universitas Islam Negeri Alauddin Makassar \\ sitiazisah@uin-alauddin.ac.id \\ Sitti Nurpahmi \\ Universitas Islam Negeri Alauddin Makassar \\ sitti.nurpahmi@uin-alauddin.ac.id
}

DOI: https://doi.org/10.24252/elties.v3i1.20235

\begin{abstract}
This research aims to design an English syllabus for Diniyah Program at Al-Qur'an Babussalam Islamic Boarding School Selayar. The research design used in this research was Research and Development $(R \& D)$ by Richey and Klein. Types of data obtained in this research were qualitative and quantitative. The researchers used a questionnaire and interview guidance as the instrument to obtain the data. This research showed that 1) speaking skill is the priority for the students: In linguistic needs, students' learning abilities are fair in vocabulary and pronunciation but less in grammar. While vocabulary is the priority, then pronunciation, and the last is grammar. There are twelve real-life topics for learning vocabulary, and pronunciation and basic grammar become integral parts of each lesson. In learning needs, vocabulary learning preferences are memorizing, communicating, listening, and repeating. While learning by imitating, from the dictionary and the recording are the pronunciation learning preferences. In terms of learning style, talking to friends in English, talking in pairs, and role play are the three highest. 2) The design syllabus is based on students' needs. 3) The syllabus validation by the experts' judgment clarified that the syllabus had been designed can be used with a bit of revision.
\end{abstract}

Keywords: Syllabus, diniyah program, need analysis.

\section{INTRODUCTION}

When the teachers start to teach at the beginning of the semester, they should have had basic ideas about what they will convey to their students. The basic ideas should have devised what they would do with students in the class for a semester. We know that before going into the classroom, a teacher must have had a learning design, start from the first meeting to the last meeting, such as the material that will be taught, what the assessment will be used, and what should be achieved by the students, that we named "syllabus."

Richards and Schmidt (2010) define a syllabus as a content description of an instruction course and how it is taught. Language-teaching syllabuses may be based on different criteria 
such as grammatical items and vocabulary. The Language is needed for different types of situations, the meanings and communicative functions which the learner needs to express in the target language, the skills underlying different language behavior, or the text types learners need to master. Richards and Schmidt also define the term syllabus design as a phase in curriculum development that deals with procedures for developing a syllabus.

Some educational institutions of Indonesia, such as elementary schools, have stipulated syllabus as a compulsory bundle for teachers in the teaching and learning process. Let us take Al-Qur'an Babussalam Islamic Boarding School (The boarding school where the researchers have studied for six years) as an example for preliminary study. In the boarding school, English is taught with an erratic schedule without a syllabus. English is taught just like that without good planning, but the students are expected to speak English and use it daily during boarding school. All Islamic students at Al-Qur'an Babussalam Islamic Boarding School must pass the English learning during three years in Junior High School until six years if they continued their study in Senior High School. Because the students are taught English without planning, learning is not patterned, so students do not know what the material is being taught to them.

Besides that, on $15^{\text {th }}$ January 2017, the researchers also have asked the leadership of Islamic Boarding School directly that there is not a good schedule for the Diniyah program in learning English. Furthermore, he said that for other Diniyah program subjects such as Aqeedah Akhlaq, Bulughul Maram, Hadith, Imla', etc. there is already a syllabus, but in learning the English Language, the Arabic Language does not exist. Besides, the researchers have made a preliminary observation on $29^{\text {th }}$ July 2017 by asking a few questions to some students, and their answer is almost in the same opinion that during in the Islamic School they are expected to speak by using the English Language in daily activity without a good system. Realizing such reality, strongly motivate the researchers to make an effort to investigate the area about designing syllabus based on students' need because this syllabus is aimed for Islamic students who are expected to use foreign Language in their daily activities while they are in an Islamic boarding environment.

\section{Some Previous Related Research Findings}

Several studies on syllabus design are based on need analysis( Kaharuddin, 2014, Dahniar, 2015). Kaharuddin (2014), in the title of the thesis "Communicative CompetenceBased Syllabus Design for Initial English Speaking Skills." His study has two main 
objectives, i.e., Firstly. His study aims to improve the quality of teaching English at the university level by aligning the students' needs and the expectations of the lecturers and graduates (a needs analysis) in designing a standard syllabus and developing teaching materials. Secondly, his research is intended to contribute to the development of theory in syllabus design since this study provides different views and syllabus design frameworks from pre-existing syllabus design frameworks for a language program. His study is restricted to gathering information on the students' needs as an essential part of designing a speaking course syllabus that focuses on Speaking course one.

The other study entitled "Developing a Task-Based Syllabus for Midwifery at UIN Alauddin Makassar" by Dahniar (2015) showed that 1) language needs of the students cover language skills and learning preferences. In language skills, speaking, listening, writing, reading is used often. In learning preferences, learning preferences in terms of learning English with others, others are studied in a small group, and study in big group, self-study, study in pairs, while learning preferences in terms of learning by using teaching technique, study through listening and speaking is preferred mainly by the students. 2) Language function used to graduate in the workplace is pregnancy, pregnancy, good food for pregnant women, diet in pregnancy, cutting the umbilical cord, and medical equipment. 3) The design syllabus is based on the students' needs.

Considering some study findings above, the similarities between previous research and current research are using the R\&D method. Meanwhile, this study's differences and previous research are the development models, research locations, and research subjects

\section{Some Pertinent Ideas}

\section{Syllabus}

Designing English Syllabus is planning instructional guidance in the learning and teaching process that contains a syllabus for one semester. David Nunan (1988) stated that the syllabus is more localized and based on accounts and records of what happens at dying classroom level as teachers and learners apply a given curriculum to their situation. According to Tom Hutchinson and Alan Waters (1991), a syllabus is a document that says what will (or at least what should) be learned. At the same time, Jack C. Richards (2001) defines a syllabus as a specification of the content of a course of instruction and lists what will be taught and tested. 
Poppy Kamalia Devi (2009) stated that syllabus development principles are scientific, relevant, systematic, consistent, adequate, actual and contextual, flexible, and complete.

\section{Diniyah Program}

Refli Sutejo (2020) said that the diniyah program is a non-formal education pathway implemented outside the formal education pathway. Diniyah subjects is a content subject with religious lessons which is expected to form positive characters towards students and can add knowledge of science religious early as possible.

\section{Need Analysis}

Need analysis is a process of collecting information about the students' needs that can be used as a reference for designing an English syllabus. Kathleen Graves (2000) stated that need assessment or need analysis is a systematic and ongoing process of gathering information about students' needs and preferences, interpreting the information, and then making course decisions based on the interpretation to meet the needs. While according to Brown (1995), need analysis is the activities involved in gathering information that will serve as the basis for developing a curriculum that will meet the learning needs of a particular group of students.

\section{METHOD}

The researchers conducted a Research and Development (R\&D). The researchers applied Richey and Klein model because it was agreed with the research focuses previously mentioned, in which the final step is product evaluation. Richey and Klein (2 010) state that Research and Development (R\&D) or Design and Development Research is the systematic study of design, development, and evaluation processes to establish an empirical basis for the creation of instructional and noninstructional products and tools and new or enhanced model that govern their development. The focus of Design and Development Research is analysis; Planning, Production, and Evaluation.

The research subjects were the Islamic boarding students in the second year at Babussalam Islamic Boarding School, and three experts have validated the syllabus. This research used a questionnaire and interview guidance as an instrument to get data from the participant about their needs in learning English. The researchers adopted Kaharuddin's 
questionnaire and interview guide to get data from the participant by the needs analysis. Besides that, the validation sheet to get the experts' judgment.

The data collection procedures deal with Richey and Klein's model, which provided the following phases: Analysis is carried out to identify the syllabus contents. Planning means the activity to plan products that have been made for a particular purpose. Planning begins with a need analysis conducted through the research and study of literature. Production is an activity to make products based on the design that has been made. Evaluation is an activity test; assess how high a product has met the specification.

\section{FINDINGS AND DISCUSSION}

\section{The students' need on English Language Teaching materials for Diniyah Program}

\section{The Review of Linguistic Needs}

Identifying linguistic needs is carried out by analyzing the students learning ability and learning priority. The analysis results are used to prioritize speaking skills and select appropriate teaching material required to design the syllabus.

\section{a. Learning Ability}

The analysis result indicates that the student's proficiency level of all the speaking components is around fair and less as indicated in the following average scores achievement; Vocabulary $(2.1=$ fair $)$, pronunciation $(2.0=$ fair $)$, and Grammar $(1.7=$ less).

Even if the students' grammar average is felt more petite, the teachers should not prioritize this component. However, grammar may not be ignored in speaking. The teachers should prioritize vocabulary and pronunciation in teaching speaking and be strengthened by grammar rules after speaking practices.

b. Learning Priority

It determines the learning priorities by analyzing the students' perceptions of the importance level of giving the speaking skills components. The result of the analysis; Vocabulary (3.8 = very important), Pronunciation (3.4 = very important), Grammar (3.0 $=$ important).

The findings above illustrate that the teachers in designing the syllabus prioritize vocabulary enrichment, the second priority to pronunciation drills, and the last priority to grammar in each unit.

c. The Needs for Learning Vocabulary and Pronunciation 
Twelve real life topics were given to the students to be selected. Here is the importance level of the topics; Daily routines $(3.6$ = very important), Getting permit $(3.3=$ very important $)$, In the mosque $(3.23=$ important $)$, Telling time $(3.2=$ important $)$, In the classroom $(3.2=$ important $)$, About days $(3.1=$ important $)$, In the dormitory $(3.1$ $=$ important $)$, Moths and dates $(3.0=$ important $)$, Money and shopping $(2.9=$ important $)$, In the canteen $(2.9=$ important $)$, Cooking and food $(2.8=$ important $)$, Clothes and colors $(2.7=$ important $)$.

Conclusively, all the speaking topics should be included since they are considered important or very important for the students to be learned in speaking.

d. The Needs for Learning Grammar

Even grammar in speaking is not very important. To learn speaking through reallife topics, the students also need to learn grammar. Some grammar items were given to be selected by all the students. The result of analysis of their perception with the grammar items are; Verb (3.6 = very important), Noun $(3.6=$ very important $)$, Adjective $(3.4=$ very important $)$, Tenses $(3.4=$ very important $)$, Pronoun $(3.3=$ very important), Adverb (3.1 = important), Conjunction (2.8 = important), Preposition (2.8 = important $)$, Interjection $(2.2=$ less important $)$.

The grammar items listed above should be adapted with the speaking topics given in each session and become integral parts of each lesson.

While we can conclude the students' linguistics need in the following table:

Table 1. The overall needs inventory from linguistic needs

\begin{tabular}{|c|c|}
\hline \multicolumn{2}{|c|}{ Linguistic Needs } \\
\hline Learning Abilities & Learning Priorities \\
\hline $\begin{array}{l}\text { 1. Fair in vocabulary } \\
\text { 2. Fair in Pronunciation }\end{array}$ & $\begin{array}{l}\text { 1. Vocabulary is the priority } \\
\text { 2. Pronunciation is the second } \\
\text { priority }\end{array}$ \\
\hline \multicolumn{2}{|c|}{ Learning vocabulary and pronunciation from real-life topics } \\
\hline $\begin{array}{l}\text { 1. Daily Routines } \\
\text { 2. Asking Permission } \\
\text { 3. In the Mosque } \\
\text { 4. Telling Time } \\
\text { 5. In the Classroom }\end{array}$ & $\begin{array}{l}\text { 7. In the Dormitory } \\
\text { 8. Months and Date } \\
\text { 9. Money and Shopping } \\
\text { 10. In the Canteen } \\
\text { 11. Cooking and Food }\end{array}$ \\
\hline
\end{tabular}




\begin{tabular}{|l|l|}
\hline 6. About Days & \multicolumn{1}{|c|}{ 12. Clothes and Colors } \\
\hline 3. Less in grammar & 3. Grammar is the third priority \\
\hline \multicolumn{2}{|c|}{ Essential grammar items to be used with vocabulary and pronunciation } \\
\hline 1. Verb & 6. Adverb \\
2. Noun & 7. Conjunction \\
3. Adjective & 8. Preposition \\
4. Tenses & 9. Interjection \\
5. Pronoun & \\
\hline
\end{tabular}

\section{The review of learning needs}

Identifying the learning needs is carried out by analyzing students learning attitudes. The researchers analyzed the students' learning preference and learning style based on their perceptions to explain the students' attitudes. Identifying the learning preferences and styles will enable the teachers to understand better the strategies and methods that might be the most efficient.

a. The Students' Learning Preferences

From the analysis results of the students, it is found out the students' preferences in learning vocabulary and pronunciation. In identifying the students' preference in vocabulary, six possible ways of learning vocabulary were given to the students, and the result of the data analysis as follow; Memorizing the vocabulary $(3.7=$ very important $)$, Communicating the vocabulary $(3.6=$ very importa nt), Listening and Repeating (3.4 = very important), Dialogues/Conversation) $(3.3=$ very important). The students' perceptions showed that four of six ways in learning vocabulary are very important.

From the analysis result of the students, it is found that the students prefer to learn pronunciation by; Learning by imitating the teacher $(3.23=$ important $)$, Learning from a dictionary $\quad(2.9=$ important $)$, Learning from recording $(2.8=$ important $)$. The data showed that all three possible ways are at the same level that important.

b. The Students' Learning Style

From the analysis result of the students, it is found that there are three highest ways of learning English for them; Talk to friends in English (3.7 = very important), Talking in pairs $(3.6=$ very important $)$, and Roleplay (3.6 = very important). But, it does not 
close the possibility for other ways to use, because it is also considered important by the students.

While we can conclude the students' learning need in the following table:

Table 2. The overall needs inventory from learning needs

\begin{tabular}{|c|c|}
\hline \multicolumn{2}{|c|}{ Learning Needs } \\
\hline The Leal & ning Attitudes \\
\hline Learning Preferences & Learning Styles \\
\hline $\begin{array}{l}\text { 1. Vocabulary } \\
\text { - Memorizing the vocabulary. } \\
\text { - Communicating the } \\
\text { vocabulary. } \\
\text { - Listening and Repeating. } \\
\text { - According to real life topics. } \\
\text { 2. Pronunciation } \\
\text { - Learning by imitating } \\
\text { teacher. } \\
\text { - Learning from dictionary. } \\
\text { - Learning from recording. }\end{array}$ & $\begin{array}{l}\text { 1. Talking to friend in English. } \\
\text { 2. Talking in pairs. } \\
\text { 3. Learning by role play. } \\
\text { 4. Learning from films and videos. } \\
\text { 5. Learning by doing tasks. } \\
\text { 6. Learning by games. } \\
\text { 7. Learning by pictures. }\end{array}$ \\
\hline
\end{tabular}

\section{The English syllabus design for Diniyah Program}

Based on the English Language Teaching material needed by the students above, it is basic information to design a set of English syllabus for the Diniyah program.

\section{The English syllabus validation by the experts' judgment}

After designing the English syllabus, it needs the experts' judgment. Three experts have given their judgment for the result of designing the syllabus. Furthermore, the three experts' judgment clarified that the researchers designed the syllabus and can be used with little revision. One of the experts has argued that some parts of the syllabus have to be right; the class of identity has to use roman number, the competency standard, and basic competence appropriate with the content standard of KTSP. Other experts have argued that the syllabus can be used without revision. The competency standard and basic competence should not be appropriate with the standard content of KTSP because designing the syllabus was based on the students' needs. 


\section{CONCLUSION}

This research showed that speaking skill is the students' priority: In linguistic needs, students' learning abilities are fair in vocabulary and pronunciation but less in grammar. While vocabulary is the priority, then pronunciation and the last is grammar. There are twelve real-life topics for learning vocabulary, and pronunciation and basic grammar become integral parts of each lesson. In learning needs, vocabulary learning preferences are memorizing, communicating, listening, and repeating. While learning by imitating, from the dictionary and the recording are the pronunciation learning preferences. In terms of learning style, talking to friends in English, talking in pairs, and role-play are the three highest. The design syllabus is based on students' needs. The syllabus validation by the experts' judgment clarified that the syllabus had been designed can be used with a revision.

\section{REFERENCES}

Brown, JD. The Elements of Language Curriculum: A Systematic Approach to Program Development. Boston: Heinle \& Heinle Publishers, 1995.

Dahniar. (2015). Developing a Task-Based Syllabus for Midwifery at UIN Alauddin Makassar. ETERNAL (English, Teaching, Learning, and Research Journal), 1(1), 112130.

Devi, PK, etc. Pengembangan Perangkat Pembelajaran. Bandung: PPPPTK IPA, 2009.

Graves, K. Designing Language Course: A Guide for Teachers. United States of Amerika: Heinle, Cengage Learning, 2000.

Hutchinson, T and Waters, A. English for Specific Purpose: A Learning-Centered Approach. $6^{\text {th }}$ Printing; Cambridge University Press, 1991.

Kaharuddin. (2014). Communicative Competence-Based Syllabus Design for Initial English Speaking Skills. International Journal of Enhanced Research in Educational Development (IJERED), 2(3), 64-83.

Nunan, D. Syllabus Design. Oxford: Oxford University Press, 1988.

Richards, JC. Curriculum Development in Language Teaching. United States of America: Cambridge University Press, 2001. 
Richards, JC, and Schmidt, R. Longman: Dictionary of Language Teaching and Applied Linguistics, 2010.

Richey, RC and Klein, JD. Design and Development Research. New York: RoutledgeTaylor and Francis Group, 2010.

Sutejo, R, etc. "Pelaksanaan Pembelajaran pada Program Diniyah untuk Anak Usia Sekolah Dasar di Desa Permata Baru Indralaya Utara Kabupaten Ogan Ilir”, Jurnal Pendidikan dan Pemberdayaan Masyarakat. https://ejournal.unsri.ac.id/index.php/jppm/article/do wnload/8308/4337 (1 October 2020) 